\title{
A Posterior Mediastinal Hydatid Cyst
}

\section{Posterior Mediastinal Kist Hidatik}

Ali Cevat Kutluk, Celalettin İbrahim Kocatürk, Suleyman Ceyhan, Levent Cansever, Mehmet Ali Bedirhan, Hasan Akin

\section{Abstract}

Hydatid disease is endemic in Turkey. Although the most common placement of this disease is in the liver and lungs in the form of a hydatid cyst, it can present in atypical localizations. Mediastinal hydatid cysts are extremely rare. To the best of our knowledge, there has been no case reported of a mediastinal hydatid cyst in a human immunodeficiency virus (HIV)-positive patient. Herein, we present to a case with a mediastinal cyst who was successfully treated with cystectomy.

Key words: Hydatidosis, echinococcal disease, mediastinal hydatic cyst, HIV-positive, cystectomy.

\section{Özet}

Kist hidatik hastalığı ülkemiz için endemik olup kist hidatiğin en sık yerleşimi karaciğer ve akciğer olmasına karşın atipik lokalizasyonlarda da ortaya çıkabilir. Mediasten yerleşimi ise oldukça nadirdir. Bununla birlikte, literatürde HIV pozitif bir olguda gelişen mediastinal kist hidatik olgusu bildirilmemiştir. Burada, kistektomi ile başarılı bir şeklide tedavi edilen bir olguyu sunuyoruz.

Anahtar Sözcükler: Hidatidozis, ekinokokal hastalık, mediastinel kist hidatik, HIV(+), kistektomi.
Hydatidosis, also referred to as echinococcosis, is a parasitic disease caused by tapeworms of the genus Echinococcus. Hydatidosis is a disease caused by the larval form of Echinococcus granulosus and is endemic in less developed and developing countries. It can be seen in different loca- tions, although it is most commonly localized in the liver and lungs. The mediastinum is one of the unusual locations for hydatid cysts $(1,2)$. Herein, we report a human immunodeficiency virus (HIV)positive case with a mediastinal hydatid cyst and discuss the atypical localization of the disease.

'Department of Chest Surgery Diseases, Yedikule Chest Disease and Thoracic Surgery Training and Research Hospital, İstanbul, Turkey

Submitted (Başvuru tarihi): 01.04.2016 Accepted (Kabul tarihi): 26.07.2016

Correspondence (iletişim): Ali Cevat Kutluk, Department of Chest Surgery Diseases, Yedikule Chest Disease and Thoracic Surgery Training and Research Hospital, İstanbul, Turkey

e-mail:dralikutluk@gmail.com 


\section{CASE}

A 29-year-old male patient was admitted to the outpatient clinic with complaints of cough and chest pain. His medical and family history revealed no indications of typical symptoms, except living in a rural area. He was smoking a pack of cigarettes/day for 10 years. His physical examination was non-specific. The laboratory examination showed that C-reactive protein level was $81 \mathrm{mg} / \mathrm{L}$ (0-5), the leukocyte count was 12,400 (3,600-10,200), the number of neutrophils was 11,200 (2000-6900), lymphocyte count was 141 (600-3400), and the monocyte count was 994 (0-900). Liver and kidney functions were normal.

A cystic lesion on the mediastinal surface of the left lung was observed in the plain graphy (Figure 1). The thoraciccomputed tomography (CT) showed a thick-walled cystic mass with a diameter of $72 \times 58 \mathrm{~mm}$, containing thin separations, in the prevascular area in the anterior mediastinum (Figure 2).

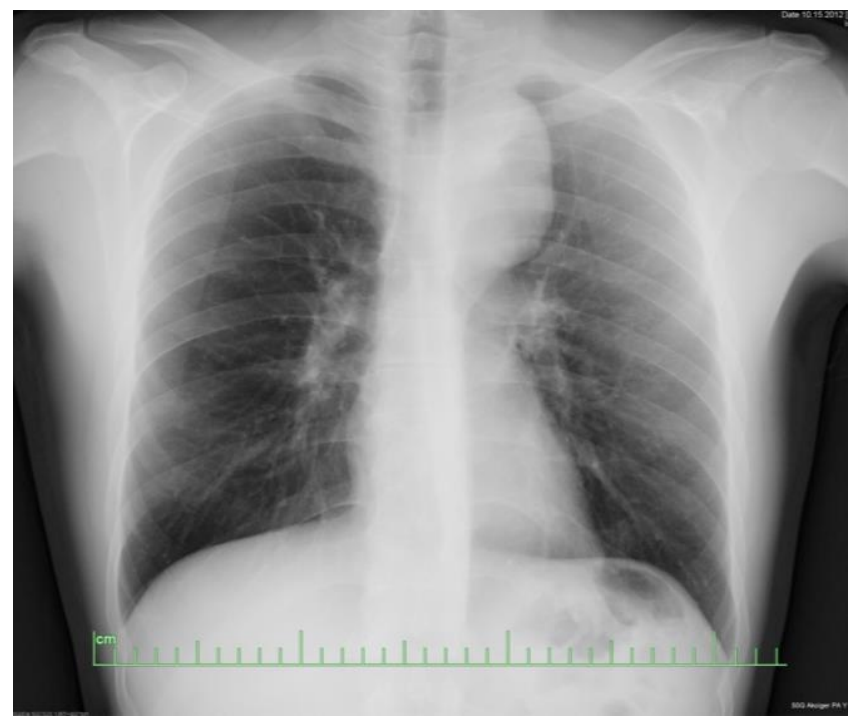

Figure 1: PA graphy shows a cystic lesion on the mediastinal surface of the left lung

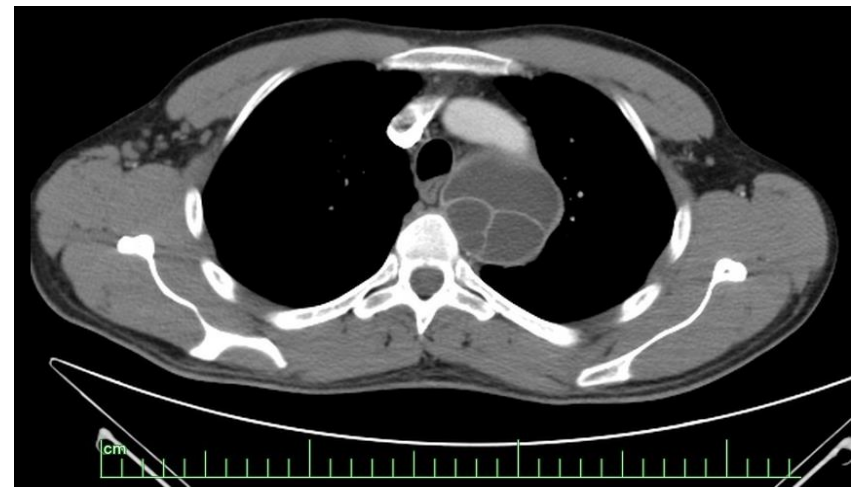

Figure 2: Computed tomography of the chest reveals a thick-walled cystic mass, with a diameter of $72 \times 58 \mathrm{~mm}$, containing thin separations, in the prevascular area of the anterior mediastinum
The cyst was located in the upper posterior mediastinum between T2 to T4 vertebrae having close relation with aortic arch, esophagus and upper lobe parenchyma. The differential diagnosis included a branchial cyst, neuroenteric cyst, and hydatid cyst.

In the routine preoperative serological examination, hepatitis B surface antigen ( $\mathrm{HbsAg}$ ) and anti-HCV were negative, while anti-HIV-positive was reported. The patient was confirmed as HIV-positive using the enzyme-linked immunosorbent assay (ELISA) kit. The patient was consulted with an infection disease specialist and Western-Blot test was done to confirm the HIV diagnosis. The immunoglobulin G (lgG) for echinococcosis was positive. There were no additional symptoms or physical examination findings regarding acquired immune deficiency syndrome. Cefazolin sodium $2 \mathrm{~g}$ was given for prophylaxis. A left axillary thoracotomy was performed. During exploration, a $7 \times 6 \mathrm{~cm}$-cyst was located in the posterior mediastinum; lying between T2-T4 vertebrae above the aortic arch without adhesions to the aorta or esophagus. After removing poor adhesions from the parenchyma, gauzes soaked with povidone-iodine were placed around the cyst to prevent inoculation. Cystotomy was performed, and all the vesicles were removed from the cyst cavity. Operation was completed resecting the cystic capsule (Figure 3). The postoperative pathological examination result was reported as a hydatid cyst (Echinococcus granulosus). The patient was discharged on Day 7 of surgery without any complications. The patient was consulted with an infectious disease specialist and put on albendazole $400 \mathrm{mg}$ treatment for a month. For opportunistic infection prophylaxis, he was given trimethoprim / sulfamethoxazole 800 / 160 mg (for Toxoplasmo gondii encephalitis, Pneumocystis carini pneumonia), clarithromycin $1000 \mathrm{mg}$ (for disseminated Mycobacterium avium complex), and flucanozole $100 \mathrm{mg}$ (for fungal infections). Influenza and hepatitis B vaccines were also given. Antituberculosis treatment was initiated, as his purified protein derivative (PPD) test result was $0 \mathrm{~cm}$. His CD4 levels (30 cells/ $\mu \mathrm{l}$ ) and HIV-RNA (>100.000 cells $/ \mathrm{mL}$ ) were measured, and he was given lopinavir $200 \mathrm{mg} /$ ritonavir 50 mg, lopinavir + ritonavir $800 / 200$ mg, and emtricitabine+ tenofovirdisoproxilfumarate 200/245 mg. After checking his blood count, liver and renal function tests, he was followed for 15-day periods. He is still disease-free with this treatment regimen for two years. 


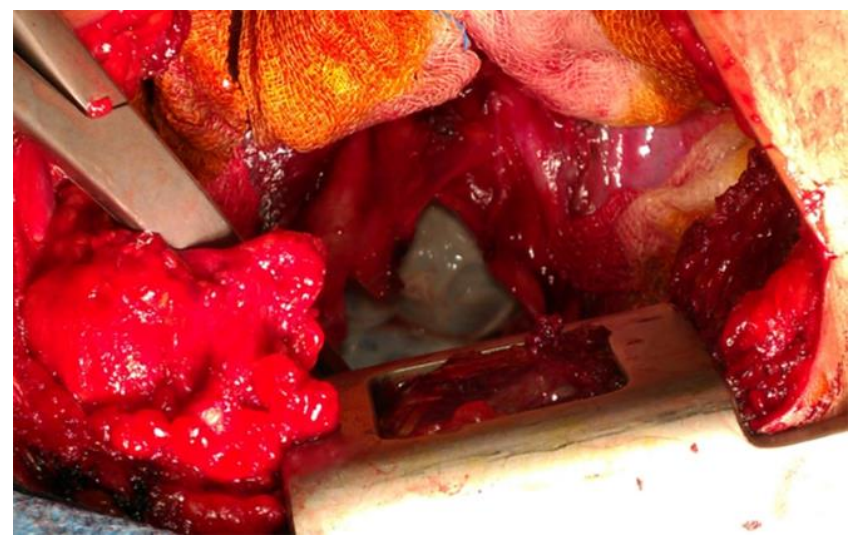

Figure 3: Operative view of the cyst following cystotomy. Multiple vesicules are clearly seen

\section{DISCUSSION}

To date, more than 100 mediastinal hydatid cyst cases have been reported in the literature. In most of these cases, the cysts were located in the posterior mediastinum. In a study evaluating 11 cases, four of the mediastinal hydatid cyst cases were located in the anterior mediastinum, 5 in the posterior mediastinum, and two in the middle mediastinum (3). However, until the present time, except a report from China in four cases with hepatic cystic echinococcosis in co-infected HIV patients, there has been no report in the literature of a mediastinal hydatid cyst in a HIV-positive patient (4).

Most lesions located in the mediastinum cause compression symptoms. These symptoms vary according to the size of the lesions, the growth rate, and the location. In a study including 27 cases with mediastinal masses, 49\% had chest pain, 37\% had dyspnea, $11 \%$ had a cough, and $3 \%$ had superior vena cava syndrome (1).

In addition to compression symptoms experienced by patients with mediastinal hydatid cysts, there may also be embolism or anaphylaxis due to the rupture of the cyst in the bronchi or vessels; spread or infection of the ruptured cyst; cord compression due to intraspinal spread; and costal, vertebral, and chest wall erosions (5). The plain graphy typically shows smooth, circular, calcified, or lowdensity mediastinal opacities, and the thoracic CT is useful in determining the morphological features, such as the right localization of the cyst, the daughter vesicles, the germinative membrane, and cyst wall calcification.

Although these tests may lead to an accurate diagnosis, this is rather atypical for mediastinum-located hydatid cysts, and the diagnosis is usually made postoperatively. In our case, pre- and postoperative serological tests for hydatid cyst were not performed. The differential diagnosis of the cysts located in the posterior mediastinum includes bronchogenic cysts, neuro-enteric cysts, and hyda- tid cysts $(6,7)$. The clinical findings, appearance of the thoracic $C T$ view, and rural living setting of the patient led to an eccinoccocal cyst, as the most possible diagnosis.

The surgical resection of the cysts located in the mediastinum remains the gold standard of the treatment (8-10). The resection can be performed by either open thoracotomy or video-assisted thoracoscopic surgery (VATS) depending on the location and size of the cyst, and also on the experience of the surgeon. Brzezinski and et al. (11) reported 50 cases with mediastinal cysts who were treated with VATS. Another study from Findikcioglu et al. (12) also reported that 12 cases with hydatid cysts were treated with VATS. We preferred open thoracotomy for the resection of the cyst, as the cyst was too large for VATS (7 $\mathrm{cm}$ in diameter). Therefore, we avoided the possibility of spillage of the vesicles into the thoracic cavity.

Until the present time, a case concerning a HIV-positive patient with a mediastinal hydatid cyst has not been reported in the literature. Surgical resection of the cysts, whether it is hydatid, bronchogenic or enteric located in the mediastinum in HIV positive patients is both effective and safe.

\section{CONFLICTS OF INTEREST}

None declared.

\section{AUTHOR CONTRIBUTIONS}

Concept - A.C.K., C.I.K., S.C., L.C., M.A.B., H.A.; Planning and Design - A.C.K., C.I.K., S.C., L.C., M.A.B., H.A.; Supervision - A.C.K., C.I.K., S.C., L.C., M.A.B., H.A.; Funding - A.C.K.; Materials - S.C.; Data Collection and/or Processing - A.C.K.; Analysis and/or Interpretation - H.A.; Literature Review - C.I.K.; Writing - A.C.K.; Critical Review - H.A.

\section{YAZAR KATKILARI}

Fikir - A.C.K., C.I.K., S.C., L.C., M.A.B., H.A.; Tasarım ve Dizayn - A.C.K., C.I.K., S.C., L.C., M.A.B., H.A.; Denetleme - A.C.K., C.I.K., S.C., L.C., M.A.B., H.A.; Kaynaklar - A.C.K.; Malzemeler - S.C.; Veri Toplama ve/veya İşleme - A.C.K.; Analiz ve/veya Yorum - H.A.; Literatür Taraması - C.I.K.; Yazıyı Yazan - A.C.K.; Eleştirel İnceleme - H.A.

\section{REFERENCES}

1. Ayan E, Balcı EA, Özalp K, Duran M, Vuraloğlu S, Çekirdekçi A. Mediastinal Kitleler: 27 Olgunun Değerlendirilmesi. Türk Göğüs Kalp Damar Cerrahisi Dergisi 2005; 13:127-30. 
2. Çağlayan K, Çelik A, Koç A, Kutluk AC, Altinli E, Celik AS, et al. Unusual locations of hydatid disease: diagnostic and surgical management of a case series. Surg Infec (Larchmt) 2010; 11:349-53. [CrossRef]

3. Eroglu A, Kurkcuoglu C, Karaoglanoglu N, Tekinbas C, Kaynar $\mathrm{H}$, Onbas $\mathrm{O}$. Primary hydatid cysts of the mediastinum. Eur J Cardiothorac Surg 2002; 22:599-601. [CrossRef]

4. Ran B, Shao Y, Guo Y, Yimiti Y, Aji T, Jia J, et al. Surgical treatment of hepatic cystic echinococcosis in patients co-infected with HIV/AIDS. J Helminthol 2016; 90:125-8. [CrossRef]

5. Karadayı Ş, Şahin E, Nadir A, Kapatanoğlu M. Posterior Mediastinumda Kist Hidatik: Olgu Sunumu. Van Tıp Dergisi 2012; 19:193-5.

6. Rahimi-Rad MH, Mahmodlou R. Multiple mediastinal hydatid cysts: a case report. Pneumologia 2009; 58:230-2.

7. Goenka AH, Das CJ, Goel P, Srinivas M, Pangtey GS. Giant primary posterior mediastinal hydatid cyst in a child: report of a case and review of literature. Pediatr Surg Int 2009; 25:647-9. [CrossRef]
8. Ozyurtkan MO, Kocyigit S, Cakmak M, Ozsoy IE, Balci AE. Case report: mediastinal hydatid cysts. Turkiye Parazitol Derg 2009; 33:179-81.

9. Gursoy S, Ucvet A, Tozum H, Erbaycu AE, Kul C, Basok O. Primary intrathoracic extrapulmonary hydatid cysts: analysis of 14 patients with a rare clinical entity. Tex Heart Inst J 2009; 36:230-3.

10. Heras F, Ramos G, Duque JL, García Yuste M, Cerezal LJ, Matilla JM. Mediastinal hydatid cysts: 8 cases. Arch Bronconeumol 2000; 36:221-4.

11. Brzeziński D, Łochowsk MP, Kozak J. Videothoracoscopy in the treatment of mediastinal cysts. Wideochir Inne Tech Maloinwazyine 2014; 9: 393-7. [CrossRef]

12. Findikcioglu A, Karadayi S, Kilic D, et al. Video-Assisted thoracoscopic surgery to treat hydatid disease of the thorax in adults: is it feasible? J Laparoendosc Adv Surg Tech A. 2012; 22:882-5. [CrossRef] 